\title{
Responses of two Sericoda Kirby, 1837 (Coleoptera: Carabidae) species to forest harvesting, wildfire, and burn severity
}

\author{
Matti Koivula, Tyler Cobb, Andrea D. Déchêne, Joshua Jacobs \& John R. Spence
}

\begin{abstract}
Koivula, M., Cobb, T., Déchêne, A. D., Jacobs, J. \& Spence, J. R. 2006: Responses of two Sericoda Kirby, 1837 (Coleoptera: Carabidae) species to forest harvesting, wildfire, and burn severity. — Entomol. Fennica 17: 315-324.
\end{abstract}

Forest fires are among the most important natural disturbances in the boreal region, but fire-initiated succession is increasingly often interrupted by salvage logging, i.e., post-fire removal of burned trees. Unfortunately, very little is known about the ecological effects of this practice. To address this knowledge gap and to examine other factors affecting the abundance of two fire-associated carabid species (Sericoda quadripuntata and $S$. bembidioides) we conducted three field studies based on pitfall trapping in recent burns in Alberta, Canada. The results suggest that the abundance of both species drastically decreased from the first to the third post-fire year and that fire severity was positively associated with abundance of both species. The combined effects of wildfire and forest harvesting were associated with higher catches of $S$. quadripunctata, but lower catches of $S$. bembidioides. We discuss these findings in the contexts of salvage logging and species ecology.

M. Koivula, T. Cobb, A. D. Déchêne, J. Jacobs \& J. R. Spence, Department of Renewable Resources, 4-42 Earth Sciences Building, University of Alberta, Edmonton AB, T6G 2E3, Canada; E-mail: mkoivula@ualberta.ca

Received 31 October 2005, accepted 25 March 2006

\section{Introduction}

Forest fires are among the most important natural disturbances in the Canadian boreal region and thus forest and fire management activities have potentially crucial effects on the abundance and distribution of arthropod species. For example, wildfires were frequent and often widespread in northern parts of Sweden until the late 1800s (Zackrisson 1977). Since then, increased access and efficient fire prevention have reduced fire frequency in Fennoscandia; the annual total land area burned in Finland and in Sweden is usually much less than a few tens of $\mathrm{km}^{2}$ (Esseen et al. 1997). Clearly, species dependent on fires (the so- called pyrophilous species) have declined in abundance along with this trend. Wikars (1992) listed 26 insect species associated with burned deciduous trees, 20 of which were classified as being nationally threatened in Sweden.

Fires remain frequent and often widespread in the Canadian boreal forest (Bergeron et al. 2001, Schneider 2002). Thus, Canadian boreal forests potentially provide "a field laboratory" to study the conditions that existed in the Fennoscandian boreal forests more than 100 years ago. However, in addition to increasing fire prevention efforts, Canadian forest industries have recently begun to harvest the burned stands right after the fire (hereafter referred to as salvage logging) to recoup 
economic losses, to aid tree regeneration, and to decrease risk of future fires. Our ability to achieve the latter two goals has recently been questioned by Donato et al. (2006), and this has stimulated a heated debate on the salvage issue (Stokstad 2006). Salvage logging also obviously removes vast amounts of potential food, shelter and nesting sites of various forest organisms. In high fireoccurrence years, this activity can account for a remarkable share of all logging. For example, in 1999 salvage logging made up over $20 \%$ of all forest harvest in Alberta (Schneider 2002). This proportion varies considerably from year to year, as the annual land area burned by forest fires in Alberta, for example, varies from a few tens of $\mathrm{km}^{2}$ to over $12,000 \mathrm{~km}^{2}$ (Schneider 2002).

Many ecological effects of forest fire are well documented, but because of its relative novelty, detailed studies of the ecological effects of salvage harvesting are few except for birds (Haggard \& Gaines 2001; Kotliar et al. 2002; Morissette et al. 2002). The present paper is thus among the first attempts to study invertebrate responses to salvage logging. As salvage logging removes much of the burned substrate it may represent a substantial threat to pyrophilous species. One of the best-studied pyrophilous carabid beetles is Sericoda quadripunctata (DeGeer, 1774). Although this species is not endangered in Finland or in Sweden (Rassi et al. 2000, Anon. 2005), it is clearly dependent on a continuous supply of recently burned habitat (Wikars 1995). Burakowski (1986) associated S. quadripunctata with recent fires and cold, moist forested habitats. A related North American species, Sericoda bembidioides Kirby, 1837 , is also thought to be a fire specialist (Larochelle \& Larivière 2003), but is much less studied.

Here, we examine the temporal occurrence, detailed micro-habitat requirements and habitat selection of these two Sericoda species. More specifically, we (1) describe the patterns of abundance of the two Sericoda species in post-fire mixed-wood forests; (2) test the hypothesis that these species will benefit from increased openness caused by salvage logging, as the practice potentially increases the ground temperature in the burned areas; and (3) test the hypothesis that these species will increase in abundance with increasing fire severity.

\section{Material and methods}

Our studies were carried out in several boreal mixed-wood forests dominated by the conifers white spruce [Picea glauca (Moench) Voss], black spruce [P. mariana (P. Mill.) B. S. P.], balsam fir [Abies balsamea (L.) P. Mill.], lodgepole pine (Pinus contorta Dougl. ex. Loud.) and jack pine ( $P$. banksiana Lamb.), and the deciduous species trembling aspen (Populus tremuloides Michx.), balsam poplar (P. balsamifera L.) and paper birch (Betula papyrifera Marsh.). These forests had burned one year prior to sampling. Beetles were sampled using plastic pitfall traps (mouth diameter $10 \mathrm{~cm}$, depth $8 \mathrm{~cm}, 30-50 \%$ propylene glycol, $15 \mathrm{~cm} \times 15 \mathrm{~cm}$ roofs installed a few $\mathrm{cm}$ above soil surface to protect the traps from litter and rain) (see Spence \& Niemelä 1994). The traps were emptied every 2-4 weeks during the frost-free period of May-August. Before the analyses, the field data were standardized to specimens/trap * day to adjust them for occasional trap losses.

We characterize habitats at two spatial scales. In the following discussion we use "micro-site" to refer to forest habitat in the scale of a few meters (i.e., immediate surroundings of pitfall traps), and "site" to designate stand features, i.e., the scale of one to several hectares. We studied the responses of Sericoda at both scales at a prescribed burn and two large wildfires.

\subsection{Prescribed-burn study}

We carried out the study near Peace River, Northwestern Alberta $\left(56^{\circ} 44^{\prime} \mathrm{N}, 118^{\circ} 20^{\prime} \mathrm{W}\right)$, during 2000-2001. The site used was a single ca. 100-yrold 10-ha stand that was burned in July 1999. The dominant canopy tree was white spruce with a small proportion of black spruce and lodgepole pine. Detailed surveys of fire impact revealed three reasonably distinct burn-severity classes, hereafter referred to as treatments:

(1) "Skips", micro-sites that had no evidence of fire (all trees alive, no signs of fire on vegetation);

(2) "Light burns", micro-sites where patches up to ca. $100 \mathrm{~m}^{2}$ of the duff layer (= the organic 
top-soil layer including litter and humus) had burned and most of the trees within the patches were dead or dying but still standing; and

(3) "Severe burns", micro-sites where most of the duff layer had burned (no understorey vegetation alive except for scattered patches of moss), all trees dead and most of them fallen.

We established four trapping sites for each treatment (each ca. 100-200 $\mathrm{m}^{2}$ ) at least $50 \mathrm{~m}$ apart and isolated from areas of a similar treatment by at least $100 \mathrm{~m}$. Pitfall-trap pairs (traps $>10 \mathrm{~m}$ apart) were deployed in each of the four trapping sites of each treatment, giving a total of 24 traps. In skips, we placed both traps in the duff with the top of the cups flush with the litter layer. In lightburn micro-sites, we placed one trap in the duff layer and the other in an adjacent patch where the duff layer had been burned, flush with the top of the remaining mineral soil. In severe burns, we placed both traps in the mineral soil where the entire duff layer had been burned. For analyses, we pooled the catches of beetles in the trap pairs within a given micro-site, as they were potentially interdependent (Digweed et al. 1995). Data were analyzed using ANOVA with repeated measures, with the two years as repeats and micro-site i.e. the three micro-site types as a factor ( 2 years $\times$ 3 treatments $\times 4$ replicates).

\subsection{Chisholm wildfire study}

In this study, we examined the combined effects of wildfire and forest harvesting. The study sites were located within and around a large-scale wildfire (ca. 1,200 $\mathrm{km}^{2}$ ) that occurred between 23 May and 4 June, 2001, near the hamlet of Chisholm, Alberta $\left(54^{\circ} 55^{\prime} \mathrm{N}, 114^{\circ} 10^{\prime} \mathrm{W}\right)$. Effects of this fire were severe in most areas, with little remaining organic matter on the forest floor and no surviving trees. The study was designed as a stand-level experiment that examined catch rates (individuals/trap * day) of each Sericoda species within five different stand treatments:

(1) Green - reference sites undisturbed by fire or harvesting in $>100$ years;

(2) Burned - sites burned during the 2001 fire;
(3) Harvested - unburned sites outside of the fire perimeter that were clear-cut logged during 2001;

(4) Salvaged - sites burned in the 2001 fire and then salvage-logged the following winter; and

(5) Burned after harvest-sites that were clear-cut in 2001 and subsequently burned in the Chisholm fire.

For each of these stand treatments, we selected six mixed-wood micro-sites (total 30) on the basis of similar pre-disturbance stand characteristics estimated from forest-inventory maps and verified on the ground wherever possible. The specific stand characteristics used in site selection were pre-fire stand age, size (3-30 ha), tree-species composition ( $>60 \%$ white spruce), stem density, under-storey plant composition, soil type, slope, and accessibility. Although Niemelä (2001) suggested that forest patches $<10$ ha do not host "true" forest carabid assemblages, we do not believe patch size affected our results because the treatments were evenly represented by different-sized patches; also, the studies reviewed by Niemelä (2001) were done in completely different, unburned environments. In our study, the minimum distance between any two sites was 1 $\mathrm{km}$. We placed traps $25 \mathrm{~m}$ apart at each site (120 traps in total) for three consecutive years following disturbance (2002-2004).

\subsection{House River wildfire study}

The House River fire took place in North-eastern

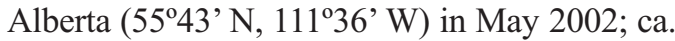
$2,700 \mathrm{~km}^{2}$ of forest was burned. Compared to the Chisholm fire, the House River fire was less severe at least in terms of ground layer affected (authors' pers. obs.) and had more site-to-site variation in burn severity (as estimated using tree and bottom-layer vegetation deaths, scorch height, and depth of burned duff). Contractors for Alberta-Pacific Forest Industries Inc. (ALPAC) salvage-harvested ca. $60-70 \%$ of the burned, mature mixed-wood forests in the area during the subsequent two winters.

We placed a total of 384 pitfall-trap pairs (two traps $4 \mathrm{~m}$ apart; data from pairs pooled for analysis) into 24 landscape-unit blocks (each $2.5 \mathrm{~km} \times$ 
$2.5 \mathrm{~km}$; blocks at least $500 \mathrm{~m}$ apart). Within each block, we deployed 16 pairs of traps located ca. 25-500 $\mathrm{m}$ apart and assumed that each catch from each pair was statistically independent (Digweed et al. 1995). The trap pairs were placed into unlogged and salvage-logged mixed-wood stands proportionally to salvage-logging intensity of each landscape unit (based on the cut-block maps from ALPAC):

(1) No salvage logging (all 16 pairs placed in unlogged mixed-wood);

(2) Low logging intensity (4 out of 16 pairs in logged stands, ca. $20-30 \%$ of merchantable mixed-wood logged);

(3) Moderate logging intensity ( 8 out of $16 ; 40$ $50 \%$ ); and

(4) High logging intensity (12 out of $16 ; 60$ $70 \%)$.

To examine the effects of fire severity, salvage logging and landscape heterogeneity, we applied statistics based on a General Linear Model (GLM). We estimated the fire scorch on trees within $8 \mathrm{~m} \times 8 \mathrm{~m}$ area surrounding each trap pair and used the fire scorch of each micro-site as a continuous variable (covariate). Fire scorch was determined for each tree within the $8 \mathrm{~m} \times 8 \mathrm{~m}$ area as follows: $0=$ unburned tree; $1=0-80 \%$ of the tree burned, $100 \%$ of its bark remaining; $2=$ $100 \%$ burned, $80-100 \%$ of bark remaining; $3=$ $100 \%$ burned, $50-80 \%$ of bark remaining; $4=$ $100 \%$ burned, $20-50 \%$ of bark remaining; and 5 $=100 \%$ burned, $<20 \%$ of bark remaining. In the analyses, we used fire scorch averages for each trap pair. We included logging as a factor by dividing the micro-sites into un-logged $(>25 \mathrm{~m}$ from forest/salvage edge; 250 trap pairs), residual (micro-sites within $25 \mathrm{~m}$ from standing-forest/salvaged-area edge or retention patches of 520 standing trees within otherwise salvaged stand; 64 trap pairs) and salvaged ( $>25 \mathrm{~m}$ from standing-forest/salvage edge; 70 trap pairs). We included the landscape variation (the 24 landscape units) in the model to examine possible large-scale variation in beetle abundance. We treated samples from the two years as repeats.
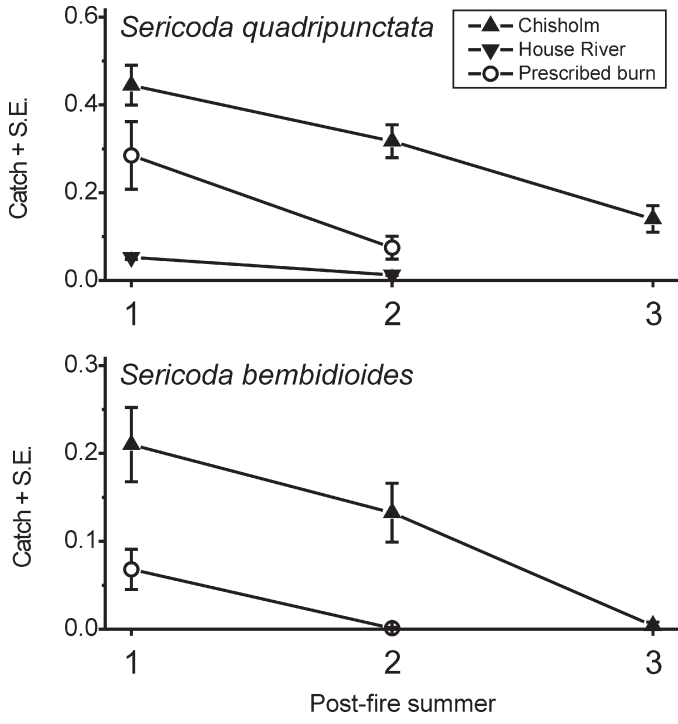

Fig. 1. Two Sericoda species caught from burned forests during the three first post-fire years. The catch $(Y$ axis) refers to data adjusted to specimens / trap * day.

\section{Results}

In the prescribed-burn, $S$. quadripunctata catches $(n=528)$ were significantly higher during the first, compared to the second, post-fire summer $(F=10.65, p=0.0039$; Fig. 1$)$. Moreover, many fewer individuals were captured from unburned micro-sites than from those that were severelyburned (unadjusted total catches 3 vs. 385), and catches in lightly-burned micro-sites were intermediate to these two extremes $(F=24.66, p$ $<0.0001$; Tukey's post hoc test for pair-wise comparisons; Fig. 2a). The significant interaction between study year and treatment $(F=9.74, p=$ $0.0054)$ indicated that the micro-site difference was much more pronounced in the first, compared to the second, year (Fig. 2a). Sericoda bembidioides $(n=94)$ was captured only in the first post-fire summer and then only in lightlyand severely-burned micro-sites. Significantly more individuals of $S$. bembidioides were captured in the severely burned micro-sites (model d.f. $=7, F=10.67, p=0.0171$ ).

At the Chisholm Fire, we caught 7,207 S. quadripunctata and 1,237 S. bembidioides adults over the three years of study. Catches of both species decreased significantly from the first to the 

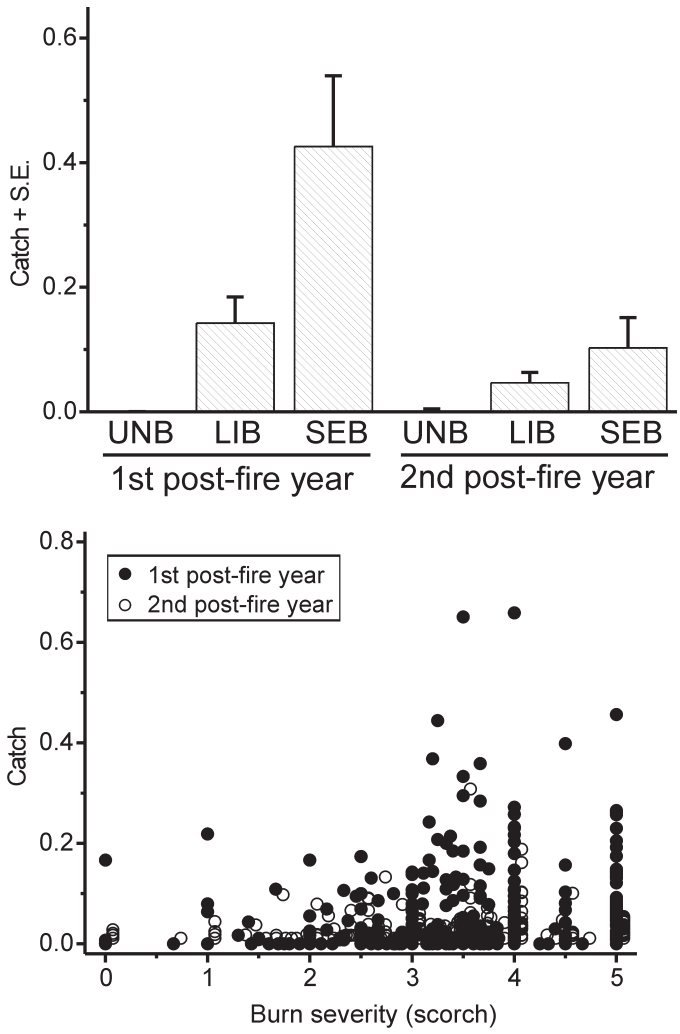

Fig. 2. Sericoda quadripunctata response to fire severity at a micro-site level. $-a$. Data from the prescribed-burn study. UNB = unburned; LIB = lightlyburned; SEB = severely-burned micro-sites. $-\mathrm{b}$. House River data. Fire severity was estimated as the average scorch class of trees within a $8 \mathrm{~m} \times 8 \mathrm{~m}$ area surrounding each micro-site (that are represented by solid symbols for 2003 and hollow ones for 2004). The catch ( $Y$ axis) in (a) and (b) refers to data adjusted to specimens / trap * day.

third post-fire summer $(F=13.65, p=0.0011$ for $S$. quadripunctata and $F=12.38, p=0.0017$ for $S$. bembidioides) (Fig. 1). There was also a strong treatment effect for both species, with respective $F$ values $53.46(p<0.0001)$ and $7.90(p=0.0002)$ (Fig. 3a). For S. quadripunctata, sites not burned (GRN and HAR) yielded significantly fewer specimens than did the other site types. Sericoda bembidioides, on the other hand, also showed a clear association to burned sites, but the species responded significantly and negatively to the combined effects of wildfire and harvesting (SAL and BAH) (Fig. 3a).

At the House River fire, we caught a total of
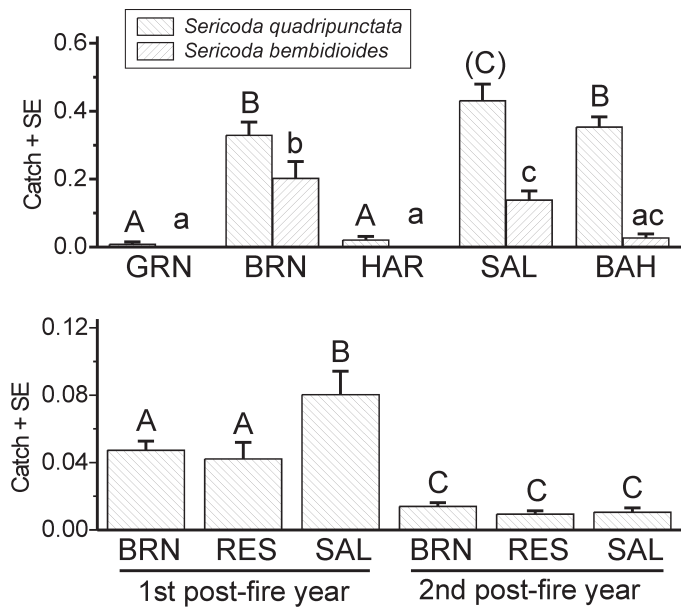

Fig. 3. The responses of two Sericoda species to post-fire (salvage) logging. GRN = un-logged and unburned (green) control; BRN = burned un-logged forest; HAR = unburned clear-cut forest; SAL = burnedthen-salvage-logged forest; $\mathrm{BAH}=$ burned-after-harvest forest; RES = residual patch retention of a few trees, or close to salvage-logged/standing-forest edge. Tukey's post hoc test results are shown with letters A-C (for S. quadripunctata) or a-c (for S.

bembidioides); marginally significant differences ( $p$ $<0.1)$ are shown in parentheses. $-a$. Chisholm fire data. - b. House River data. The catch (Y axis) in (a) and in (b) refers to data adjusted to specimens / trap * day.

2,266 S. quadripunctata specimens in 2003 as compared to only 624 in 2004 . Only 4 adult $S$. bembidioides were caught at House River (all in 2003), and this species was therefore excluded from the analysis. The GLM with repeated measures for $S$. quadripunctata showed highly significant effects of sampling year (higher catches in $2003 ; F=70.03, p<0.0001$ ), scorch height (positive abundance vs. fire-severity relationship; $F=$ $4.09, p=0.0440)$ and landscape unit (= largescale variation within the fire; $F=2.70, p$ $<0.0001$ ) (Figs. 1, 2b, 3b). Also salvage logging had a significant effect on $S$. quadripunctata catch $(F=4.93, p=0.0079)$, which corroborates the Chisholm results. The Tukey's post hoc test indicated that salvaged sites hosted significantly higher catches than did un-logged and residual micro-sites (Fig. 3b). Apart from the interaction between year and logging (the micro-site difference being clearly more pronounced for the first, compared to the second, post-fire summer; Fig. 
3b), none of the model interaction terms were significant. The significant variables together explained $30.3 \%$ of the variation in the data (year: 14.5\%, logging: $2.0 \%$, scorch: $0.8 \%$, landscape: $12.9 \%)$. After fitting the full model, $57.7 \%$ of the variation remained unexplained (model d.f. $=$ 106 , error-term d.f. $=278$ ).

\section{Discussion}

In all three of the field datasets, pitfall captures of S. quadripunctata and S. bembidioides decreased dramatically from the first to the third post-fire year. This result confirms similar observations for the former species by Holliday (1984), Ehnström (1991) and Gongalsky et al. (2003). Increased catches of $S$. quadripunctata were associated with the increased openness caused by salvage logging, whereas $S$. bembidioides showed an opposite response to salvaging. Both species, however, were positively associated with increasing micro-site burn severity.

The rapid appearance of Sericoda to recent fires can be explained by two life-history factors. Sericoda quadripunctata has reportedly been abundant in seashore drift (Burakowski 1986), suggesting dispersal by flight, and it has a high reproductive rate: the development from the firstinstar larva to adult takes only 20-37 days, the longer periods being the rule in early fall (Burakowski 1986). Another, completely different, explanation for the rapid appearance of $S$. quadripunctata at fires was presented by Burmeister (1955) who suggested that the species might live a subterranean life e.g. in burrows of small mammals, and fire would force the specimens to the soil surface (and into pitfall traps). However, if that hypothesis were correct, Wikars (1995) should have found the species more abundantly in burned clear-cuts with potentially more intense ground fire, compared to standing burned forests. In Sweden, burning after clear-cutting does not produce conditions required to attract $S$. quadripunctata, whereas burning of standing forests does (Wikars 1995). We detected a similar result for $S$. bembidioides, but interestingly in Alberta catches of $S$. quadripunctata did not differ between these two treatments in the Chisholm fire data (compare the BRN and BAH columns in
Fig. 3a). Such contradictory results may be related to differences in the ecology of $S$. quadripunctata between Sweden and Alberta and/or in the landscape-level past and present fire frequency. It is possible, for example, that in Sweden where recent times have been characterized by low fire frequency, much more fuel is needed to attract $S$. quadripunctata specimens from the presumably scattered small populations that continue to exist, whereas in Alberta, with roughly comparable land area but much more forest burning annually, the species may be generally more abundant and widespread. Variation in burn-severity among individual fires may also play a role in determining the large-scale abundance of the species, as indicated by the much higher catches of $S$. quadripunctata in the more severely burned Chisholm than in the House River fire area.

Salvage logging had a significant positive effect on S. quadripunctata catches. We suggest that the initial attraction of $S$. quadripunctata specimens to burns is amplified if followed by salvaging. Salvaging must somehow improve the quality of the habitat for S. quadripunctata. Individuals of this species may be attracted to burned woody material (see below), but this response is likely to be short-lived because the dispersal of individuals to suitable breeding sites appears to last only 1-2 years after fire. Compared to unburned forests and clear-cuts, Sericoda in recent burns may experience less inter-specific competition, as the fire may directly kill a high percentage of top-soil invertebrates (e.g., Wikars \& Schimmel 2001). In addition, the black charcoal-covered ground probably efficiently stores heat and promotes higher temperatures in these microhabitats. Salvaging the remaining trees opens the stands up to the sun and perhaps allows the forest floor to become even warmer.

As salvage logging removes a considerable number of dead standing trees and consequently decreases the amount of potential feeding and nesting places for dead-wood dependent organisms, the results for $S$. quadripunctata should be interpreted cautiously. The negative response of $S$. bembidioides to salvage logging in the Chisholm fire may reflect needs for conditions associated with a certain amount and/or quality of dead trees. Such requirements may be associated with over-wintering habits [e.g., many carabids over- 
winter under tree bark (Thiele 1977)] and we observed over-wintering adult $S$. quadripunctata specimens under the bark of fire-killed white spruce trees during the first winter after the Chisholm fire (authors' pers. obs.). Requirements for dead wood could also be related to behavior [some species spend part of their life cycle in trees (Lindroth 1985, 1986)] or breeding biology [Burakowski (1986) showed that dead wood is a possible egg-laying substrate for some $S$. quadripunctata females]. We therefore recommend that salvage-logging studies should also be carried out on taxa that are more directly connected with dead wood.

The House River data revealed that the largescale variation in abundance (in the scale of up to hundreds of $\mathrm{km}^{2}$ ) significantly determines the local abundance of $S$. quadripunctata. This result cannot be explained by some regular large-scale environmental gradient, as the latitude and longitude coordinates of the trapping sites did not correlate with burn severity estimates (scorch, depth of burned duff, or field estimation of tree survival). On the other hand, burn severity at this scale - despite being significant - explained very little of the overall variance. Thus, fire severity was a predictable determinant of $S$. quadripunctata abundance in many (but not all) sites despite the fact that the species was rather evenly, but sparsely distributed over the fire area (see Fig. 1 and above discussion on larger-scale abundance patterns in Sweden and Alberta). Moreover, almost $60 \%$ of the overall variation of $S$. quadripunctata remained unexplained.

Micro-site structure can be important. For example, in a laboratory study Burakowski (1986) reported that $S$. quadripunctata females most often lay eggs within and on bare clay and soil. This suggests a partial mechanistic explanation for the positive response to increased burn severity shown in our study, i.e., that more severely burned areas, with more bare mineral soil, are important for reproduction by this species. Detailed studies on soil moisture, vegetation, and forest structural and topographic characteristics may help to further elucidate the explanation for the curiously scattered abundance of Sericoda on boreal landscapes. We also suggest that more work should be aimed at understanding the relative importance of the "matrix" (here, habitat types we did not study, such as jack pine and black spruce) and unburned residual patches for determining Sericoda occurrence and abundance (see Gandhi et al. 2001).

Factor(s) hypothesized to attract S. quadripunctata to recently-burned areas include chemical substances of wood, smoke per se, and even heat and light (e.g., Lindroth 1945, 1986, Burakowski 1986, Wikars 1995). To study the importance of these factors we captured live adults of $S$. quadripunctata $(n=25)$ and $S$. bembidioides $(n=$ 8 ) from the Chisholm area during the second post-fire summer and subjected these to a series of paired preference experiments (Raffa et al. 2002). Our aim was to test beetle response to the smoke and charcoal of conifers (white spruce, balsam fir) and deciduous trees (trembling aspen and paper birch), and to heat and light (that was used in combination with heat). We used $1.2-\mathrm{cm}$ diameter plastic T-shaped tubing with each "branch" ca. $15 \mathrm{~cm}$ and an air vacuum to draw in equal air from the control (= nothing) and stimulus ends of the apparatus. The direction from which the stimulus came was randomized, and potentially contaminated parts of the apparatus were switched between trials. One randomlychosen specimen at a time was released in the apparatus and its movement toward (positive) or away from (negative) the stimulus was recorded. A $G^{2}$ test for the data showed that $S$. quadripunctata responded marginally significantly ( $p$ $<0.1)$ and negatively to spruce smoke but positively to aspen $(p<0.1)$ and fir $(p<0.05)$ charcoal; moreover, $S$. bembidioides responded significantly negatively to spruce and aspen smoke. We did not detect significant responses to heat (ca. $+40 \ldots+43^{\circ} \mathrm{C}$ ) or light (3-watt incandescent bulb).

The appearance of Sericoda in areas shortly after a fire is consistent with the positive trend in their response to charcoal (see previous paragraph), but the negative response to smoke contradicts previous suggestions (e.g., Lindroth 1945, Burakowski 1986). Melanophila acuminata (De Geer, 1774), another pyrophilous beetle, is attracted to infra-red radiation (Evans 1966, 1971), whereas Sericoda did not appear to be attracted by light (nor by heat). The lack of significant response to light contradicts with Larochelle \& Larivière (2003) who reported both species be- 
ing frequently caught using light traps. However, the results of this pilot study should be interpreted with caution as the beetles were responding by walking not by flying, the latter likely being the main method of dispersal (Burakowski 1986, Lindroth 1986), and it was uncertain whether the beetles were at a dispersal phase of their life cycle. Unfortunately, we were unable to initiate a flight response in the laboratory.

The drastic decreases of the two Sericoda species from the first to the third post-fire summer may be related to the field-layer vegetation succession. Compared to $S$. quadripunctata, $S$. bembidioides showed a much steeper decrease and was absent in the third post-fire summer (Fig. 1). Thus, even subtle increases in vegetation cover might significantly affect this species by changing the shadiness and temperature of forest floor. In Central America, $S$. bembidioides is often abundant at sun-exposed, unburned sites (George E. Ball, pers. comm.), whereas at more northern latitudes it may find appropriate (open and warm) breeding sites only at recent severe burns. Such dependence might explain the low S. bembidioides abundance at the House River fire: there, field layer was generally much less affected by the fire than in the other two studies. Another factor that may contribute to the rapid decrease of these species at wildfires are un-described species of Antennoseius Berlese, 1916 (Acari: Ascidae) mites that we have often found in abundance (up to a few tens per beetle) under the elytra of both species (A. D. Déchêne, unpubl. data). Whether or not these mites are parasitic or phoretic remains unclear.

Our field studies revealed that fire severity was a critical determinant of Sericoda micro-site level abundance in post-burn forests, and that both $S$. bembidioides and S. quadripunctata probably are common for only a few years after wildfires. Sericoda abundance differed among the three studies (Fig. 1). This result may reflect year-to-year variation, but it could also be related to burn severity and vegetation recovery (see above). Due to the transient nature of wildfire areas remaining suitable for these species, widespread persistence of these species on boreal landscapes may depend on the frequency and area of future fires. Furthermore, salvage logging positively affected $S$. quadripunctata (probably due to the increased openness and related soiltemperature increase), but negatively affected $S$. bembidioides. The latter species thus seems to be either strictly associated with standing burned trees, or is negatively affected by the loggingcaused increase of logging debris (shadiness; see discussion above). The oviposition and moulting of larvae of S. quadripunctata often takes place in crevices of small pieces of dead burned wood [twigs of a few $\mathrm{mm}$ in diameter (Burakowski 1986)], and indeed the amount of downed dead wood increases in salvaged areas due to the accumulation of logging debris (Donato et al. 2006).

Maintenance of local Sericoda populations probably depends on the retention of burned wood in at least some reasonably large (several ha) patches. Until recently, only 2 out of 16 forestry companies in Alberta retained any burned, merchantable wood in post-fire harvest operations (Anon. 2001), but this practice is changing. For example, ALPAC currently retains $30-40 \%$ of fire killed stands un-salvaged (Elston Dzus, ALPAC, pers. comm.). At present, general guidelines and policy for retention of standing burned trees and other post-fire management issues for Alberta and other Canadian provinces are under development. Policy and guidelines in support of high retention in post-fire management will likely benefit dead wood- and fire-dependent forest organisms. However, as current salvage harvesting practices generally focus on lightly-burned trees, the ecological significance of burn severity should be considered in developing the 'best practice' recommendations for retention of burned dead wood.

Acknowledgements. We thank the following persons (in alphabetical order) for contributing to study planning and field and laboratory work: Erin Bayne, Lisa Best, David Bywater, Lynnette Dagenais, Dustin Hartley, Derek Keeping, David Langor, Ellen Macdonald, Becky Motuzas, Lynsey Mozak, Michael Norton, Anne Ollila, Iain Phillips, Delanie Player, Sabrina Romanchuk, Fiona Schmiegelow, Simon Slater, David Stepnisky and Lisa Tidman. Two anonymous referees and Gabor Lövei provided valuable comments; Gabor also took over the editorial duties for this paper. The prescribed burn project was funded by grants given to the EMEND (Ecosystem Management Emulating Natural Disturbance) by Canadian Forest Products (Canfor) and Daishowa Marubeni International (DMI). The Chisholm Fire project and the laboratory experiment 
were funded by the Foothills Model Forest ChisholmDogrib Fire Research Initiative, the Sustainable Forest Management Network, the Alberta Conservation Association supported Biodiversity Challenge Grants Program, Weyerhaeuser Company Canada, Canadian Forest Service, and the Natural Science and Engineering Research Council (NSERC). The House River Fire project field work was funded by the Alberta-Pacific Forest Industries Inc. MK thanks the University of Alberta (Izaak Walton Killam Postdoctoral Fellowship) for funding.

\section{References}

Anon. 2001: Planning and Practices Survey of FMA Holders in Alberta. - Forest Watch Alberta; http://www. forestwatchalberta.ca/forestry/survey.html. (Access date 24 July 2005)

Anon. 2005: Official Swedish Red Lists. - SLU ArtDatabanken, Sweden; http://www.artdata.slu.se/ rodlista. (Access date 24 July 2005)

Bergeron, Y., Gauthier, S., Kafka, V., Lefort, P. \& Lesieur, D. 2001: Natural fire frequency for the eastern Canadian boreal forest: consequences for sustainable forestry. - Canadian Journal of Forest Research 31: 384-391.

Burakowski, B. 1986: The life-cycle and food preference of Agonum quadripunctatum (De Geer). — In: Den Boer, P. J., Grüm, L. \& Szyszko, J. (eds.), Feeding behaviour and accessibility of food for carabid beetles: 35-39. Warsaw Agricultural University Press.

Burmeister, F. 1955: Was wissen wir vom Leben der Käfer? - Mitteilungen der Deutschen Entomologischen Gesellschaft 14: 14-16.

Digweed, S. C., Currie, C. R., Cárcamo, H. A. \& Spence, J. R. 1995: Digging out the "digging-in-effect" of pitfall traps: influences of depletion and disturbance on catches of ground beetles (Coleoptera: Carabidae). Pedobiologia 39: 561-576.

Donato, D. C., Fontaine, J. B., Campbell, J. L., Robinson, W. D., Kauffman, J. B. \& Law, B. E. 2006: Post-wildfire logging hinders regeneration and increases fire risk. - Science 311: 352.

Ehnström, B. 1991: Många insekter gynnas. — Skog och Forskning 4: 47-52. [In Swedish.]

Esseen, P.-A., Ehnström, B., Ericson, L. \& Sjöberg, K. 1997: Boreal forests. — Ecological Bulletins 46: 1647.

Evans, W. G. 1966: Perception of infrared radiation from forest fires by Melanophila acuminata De Geer (Buprestidae, Coleoptera). — Ecology 47: 10611065.

Evans, W. G. 1971: The attraction of insects to forest fires. - In: Proceedings of Tall Timbers Conference in Ecological Animal Control by Habitat Management. No. 3: 115-127. Tallahassee, Florida.

Gandhi, K. J. K., Spence, J. R., Langor, D. W. \& Morgantini, L. E. 2001: Fire residuals as habitat reserves for epigaeic beetles (Coleoptera: Carabidae and Staphy- linidae). - Biological Conservation 102: 131-141.

Gongalsky, K. B., Wikars, L.-O. \& Persson, T. 2003: Dynamics of pyrophilous carabids in a burned pine forest in central Sweden. - Baltic Journal of Coleopterology 3: 107-111.

Haggard, M. \& Gaines, W. L. 2001: Effects of stand-replacement fire and salvage logging on a cavity nesting bird community in eastern Cascades, Washington. Northwest Science 75: 387-396.

Holliday, N. J. 1984: Carabid beetles (Coleoptera: Carabidae) from a burned spruce forest (Picea spp.). - Canadian Entomologist 116: 919-922.

Kotliar, N, B., Hejl, S. J., Hutto, R. L., Saab, V. A., Melcher, C. P. \& McFadzen, M. E. 2002: Effects of fire and post-fire salvage logging on avian communities in conifer-dominated forests of the western United States. - Studies in Avian Biology 25: 49-64.

Larochelle, A. \& Larivière, M.-C. 2003: A Natural History of the Ground-Beetles (Coleoptera: Carabidae) of America north of Mexico. - Pensoft Publishers, Sofia-Moscow. 583 pp.

Lindroth, C. H. 1945: Die Fennoscandischen Carabidae. Eine Tiergeographische Studie. I. Spezieller Teil. Elanders Boktryckeri Aktiebolag, Göteborg. 709 pp.

Lindroth, C. H. 1985: The Carabidae (Coleoptera) of Fennoscandia and Denmark. Vol. 15, part 1. - Fauna Entomologica Skandinavica, Leiden, Kopenhagen. $227 \mathrm{pp}$.

Lindroth, C. H. 1986: The Carabidae (Coleoptera) of Fennoscandia and Denmark. Vol. 15, part 2. - Fauna Entomologica Skandinavica, Leiden, Kopenhagen. $272 \mathrm{pp}$.

Morissette, J. L., Cobb, T. P., Brigham, R. M. \& James, P. C. 2002: The response of boreal forest songbird communities to fire and post-fire harvesting. - Canadian Journal of Forest Research 32: 2169-2183.

Niemelä, J. 2001: Carabid beetles (Coleoptera, Carabidae) and habitat fragmentation: a review. - European Journal of Entomology 98: 127-132.

Raffa, K. F., Havill, N. P. \& Nordheim, E. V. 2002: How many choices can your test animal compare effectively? Evaluating a critical assumption of behavioral preference tests. - Oecologia 133: 422-429.

Rassi, P., Alanen, A., Hakalisto, S., Hanski, I., Lehikoinen, E., Ohenoja, E., Siitonen, J., Suvantola, L., Vitikainen, O., Väisänen, R., Kanerva, T. \& Mannerkoski, I. 2000: Suomen lajien uhanalaisuus 2000. Uhanalaisten lajien II seurantatyöryhmä. - Finnish Ministry of Environment. 432 pp. [In Finnish.]

Schneider, R. R. 2002: Alternative Futures. Alberta's Boreal Forest at the Crossroads. - The Federation of Alberta Naturalists and the Alberta Centre for Boreal Research, Edmonton. 152 pp.

Spence, J. R. \& Niemelä, J. K. 1994: Sampling carabid assemblages with pitfall traps: the madness and the method. - The Canadian Entomologist 126: 881894.

Stokstad, E. 2006: Salvage logging research continues to generate sparks. - Science 311: 761.

Thiele, H.-U. 1977: Carabid Beetles in their Enviroments. 
A Study on Habitat Selection by Adaptation in Physiology and Behavior. Zoophysiology and Ecology 10. Springer Verlag, Berlin. 369 pp.

Wikars, L.-O. 1992: Skogsbränder och insekter. — Entomologisk Tidskrift 113: 1-11. [In Swedish with English summary.]

Wikars, L.-O. 1995: Clear-cutting before burning prevents establishment of fire-adapted Agonum quadripuncta- tum (Coleoptera, Carabidae). - Annales Zoologici Fennici 32: 375-384.

Wikars, L.-O. \& Schimmel, J. 2001: Immediate effects of fire-severity on soil invertebrates in cut and uncut pine forests. - Forest Ecology and Management 141: 189200.

Zackrisson, O. 1977: Influence of forest fires on the North Swedish boreal forest. — Oikos 29: 22-32. 